\title{
Efficient Coupling of DNA on a Silica Support with Psoralen Derivatives as Anchoring Agents for High-Performance Liquid Affinity Chromatography
}

\author{
Shotaro Kashiwagi, Kazuhiro OHMori, Mizuo MaEda and Makoto Takagi \\ Department of Chemical Science and Technology, Faculty of Engineering, Kyushu University, \\ Hakozaki, Fukuoka 812, Japan
}

\begin{abstract}
Keywords DNA-immobilized silica gel, psoralen derivative, high-performance liquid affinity chromatography, DNA-drug interaction, polycyclic aromatic molecule
\end{abstract}

The weak-affinity chromatography or high-performance liquid affinity chromatography (HPLAC) is a promising tool for the identification, isolation and systematic investigation of the components of weak (readily reversible) bioaffinity reactions. ${ }^{1,2}$ A high concentration of a ligand coupled to the solid phase is a prerequisite in this case.

In addition to some enzyme-substrate ${ }^{3}$ and IgGantigen ${ }^{4}$ combinations to which the method has been successfully applied, weak bindings of biological importance involve a DNA-drug interaction. This interaction is usually evaluated by spectral titration and equilibrium dialysis. ${ }^{5}$ Since these methods require time-consuming procedures, they do not appear to be suitable for a systematic investigation of a series of drug analogues. In addition, the methods are only applicable to systems with relatively strong affinity. In this context, an HPLAC using a DNA-immobilized support appears to be promising to study DNA-drug interactions. ${ }^{6}$ So far, an efficient coupling method is not available for DNA, since polynucleotides lack highly reactive groups.

We report here on a general and convenient method for covalent coupling of double-stranded DNA on a solid support. This method relies on a psoralen derivative (1) which can form a photoadduct with the duplex DNA. Since coupling chemistry permits a large amount of DNA to be immobilized on a macroporous silica support (10 $\left.\mathrm{mg} \mathrm{g} \mathrm{gel}^{-1}\right)$, the concept of weak-affinity chromatography can be applied. Preliminary results are presented regarding DNA-drug interactions by using a DNA-loaded column.

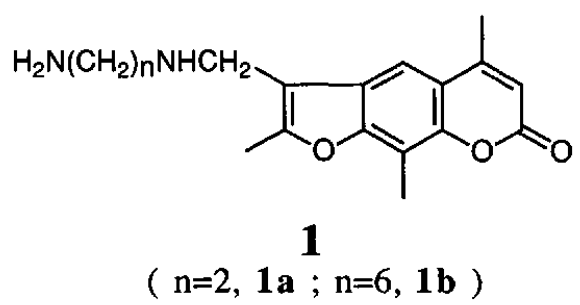

\section{Experimental}

Synthesis of anchoring reagents (1)

$4^{\prime}$-[[ $N$-(2-Aminoethyl)amino]methyl]-4,5',8-trimethylpsoralen $(1 \mathrm{a} ; n=2)$ was synthesized according to a method described by Lee et al. ${ }^{7} \quad \mathbf{1 b}(n=6)$ was prepared similarly, though the product was isolated as a dihydrochloride and then recrystallized from methanol-diethyl ether. Yield, $16.2 \%$. Elemental analysis of the salt: Found: $\mathrm{C}, 56.89 ; \mathrm{H}, 6.85 ; \mathrm{N}, 6.43 \%$. Calcd for $\mathrm{C}_{21}$ $\mathrm{H}_{30} \mathrm{O}_{3} \mathrm{~N}_{2} \mathrm{Cl}_{2}+0.75 \mathrm{H}_{2} \mathrm{O}: \mathrm{C}, 56.95 ; \mathrm{H}, 7.16 ; \mathrm{N}, 6.32 \%$.

\section{Coupling of DNA to silica gel}

A silica gel (Nagel, Nucleosil 1000-5; diameter, $5 \mu \mathrm{m}$; pore, $1000 \AA$; surface area, $25 \mathrm{~m}^{2} \mathrm{~g}^{-1}$ ) was modified with epoxy groups according to a method described in the literature. 1,3 was then reacted with the epoxy-silica (the epoxy group content, $46 \mu \mathrm{mol} \mathrm{g}^{-1}$ ) in $0.1 \mathrm{M}$ sodium pyrophosphate $(\mathrm{pH} 8.5)$ for $40 \mathrm{~h}$ at $25^{\circ} \mathrm{C}(1 \mathrm{~g}$-gel with $3 \mu \mathrm{mol}$ of 1 in $4 \mathrm{ml}$ of the buffer). The reaction and the subsequent procedures were all dark adapted. The psoralen-modified silica was treated with an aqueous solution (1 M) of 2-mercaptoethanol for converting the residual epoxy groups into hydrophilic diols. The psoralen content was determined for gel suspension in $67 \mathrm{wt}-\%$ aqueous sucrose $\left(6 \mathrm{mg}^{-} \mathrm{gel} \mathrm{ml}^{-1}\right)$ by UV spectrophotometry $\left(\lambda_{\max }, 300\right.$ and $\left.340 \mathrm{~nm}\right)$, and was found to be 2.07 and $1.12 \mu \mathrm{mol} \mathrm{g}^{-\mathrm{gel}^{-1}}$ for $1 \mathrm{a}$ and $\mathbf{1 b}$, respectively.

The psoralen-bearing silica gel $(1 \mathrm{~g})$ was suspended in a $3 \mathrm{ml}$ solution $\left(20 \mathrm{mg} \mathrm{ml}^{-1}\right)$ of sonicated calf thymus DNA $\left(10^{2}-10^{3} \mathrm{bp}\right)$ in a buffer $(10 \mathrm{mM}$ phosphate, $1 \mathrm{mM}$ EDTA, $0.2 \mathrm{M} \mathrm{NaCl}, \mathrm{pH}$ 6.6). The suspension in a Pyrex vessel was rotated on an ice bath with a rotary evaporator, and then was irradiated $\left(c a .60 \mathrm{~mW} \mathrm{~cm}^{-2}\right)$ with a highpressure $\mathrm{Hg}$ lamp for $2 \mathrm{~h}$. The silica gel was washed successively with water, $10 \mathrm{mM}$ Tris- $\mathrm{HCl}-2 \mathrm{M} \mathrm{NaCl}$ (pH 7.2), $10 \mathrm{mM}$ Tris-HCl-1 mM EDTA-0.1 M NaCl (pH 7.2), 0.4 M MES ( $\mathrm{pH} 6.0$ ), and $1 \mathrm{M}$ phosphate 
(pH 7.6). The silica gel was preserved in $10 \mathrm{mM}$ Tris$\mathrm{HCl}-1 \mathrm{mM}$ EDTA-0.1 $\mathrm{M} \mathrm{NaCl}(\mathrm{pH} 7.2)$ at $5^{\circ} \mathrm{C}$. For determining the amount of DNA bound to the silica, the gel dried in vacuo $(50 \mathrm{mg}$ ) was digested with $1.2 \mathrm{ml}$ of $0.4 \mathrm{M}$ perchloric acid for $30 \mathrm{~min}$ at $70^{\circ} \mathrm{C}$; the nucleotides in the supernatant were determined by the diphenylamine reaction. ${ }^{8}$

\section{High-performance liquid affinity chromatography}

The DNA-loaded silica support was packed into a $4.6 \mathrm{~mm}$ i.d. $\times 7.5 \mathrm{~cm}$ stainless-steel column by standard slurry procedures. A Shimadzu Model LC-5A liquid chromatograph with a Rheodyne Model 7125 sampling valve and a $50 \mu 1$ injection loop was operated at $23^{\circ} \mathrm{C}$ with a Union-Giken Model MCPD-350PC detector system. The mobile phase consisted of a mixture of Tris- $\mathrm{HCl}$ (10 mM, pH 7.4)-EDTA (1 mM)-NaCl (a prescribed concentration) and acetonitrile $(9: 1$ by volume). The flow rate was $0.5 \mathrm{ml} \mathrm{min} \mathrm{m}^{-1}$.

\section{Results and Discussion}

The amount of DNA immobilized was determined to be 8.4 and $10.2 \mathrm{mg} \mathrm{g-gel}^{-1}$ for $1 \mathrm{a}$ - and $\mathbf{1 b}$-bearing gel, respectively, by using the diphenylamine method for perchloric acid digests. The values were in fair agreement with those estimated from UV absorption at $260 \mathrm{~nm}$ of the gel suspension in $67 \mathrm{wt}-\%$ aqueous sucrose. The UV spectra also showed that the absorbance at $340 \mathrm{~nm}$ was reduced by a photochemical reaction to $30 \%$ of the original, indicating that at least $70 \%$ of the psoralen derivative gave a photoadduct with DNA. ${ }^{9}$ Thus, an efficient coupling of DNA covalently to the silica gel support (up to $10 \mathrm{mg} \mathrm{g}$-gel $^{-1}$ ) was attained with the aid of 1 residues.

Cyanogen bromide has been widely used to couple DNA with biopolymer-based supports including agarose gel, though the amount of DNA immobilized was rather limited (typically, 3-30 $\mathrm{g} \mathrm{ml-gel}^{-1}$ ). ${ }^{10,11}$ Sonicated
DNA has been attached to dextran gel in high concentrations $\left(10-38 \mathrm{mg} \mathrm{ml}^{\left.-\mathrm{gel}^{-1}\right)}\right.$ by a carbodiimide method. ${ }^{12}$ Supports made of polysaccarides are, however, improper for use in HPLC. Modifications of DNA with reactive group(s) made it possible to conjugate DNA with silica and organic gels. ${ }^{6,13,14}$ These methods, however, require expert synthetic procedures for premodifying each DNA of interest.

In our method presented here, the chemistry is based on the intercalation of furocoumarins into DNA and photosensitized conjugation between them. Since this reaction is general, a series of double-stranded DNA can be covalently immobilized on any 1-bearing solid support.

A preliminary experiment was carried out to evaluate the interaction between DNA and polycyclic aromatic compounds (PAC's), some of which are known to be DNA-intercalators; PAC's are mutagenic and/or carcinogenic due to some interaction with DNA. The results are summarized in Table 1 along with those for DNA-free 1b-bearing packings used as a reference. The capacity factor $\left(k^{\prime}\right)$ is found to be dependent on the structure of the compounds, as well as the ionic strength of the eluent. The values of $k^{\prime}$ for methyl 9 -acridinecarboxylate and 4,5',8-trimethylpsoralen appear to be correlated with the magnitudes of the association constant ( $\left.K_{\text {ass }}\right)$ determined for their intercalative binding with DNA. ${ }^{15,16}$ This suggests that the retention on a DNA-loaded column of the compounds is governed by their affinity toward DNA. It is reported that the affinity with DNA of a certain intercalator decreases with increasing ionic strength. ${ }^{17}$ This was the case in our data for nonionic compounds; the capacity factors decreased with increasing concentration of $\mathrm{NaCl}$ in the eluent. Tricyclic compounds, such as phenanthrene are, therefore, considered to be intercalative to DNA with a $K_{\text {ass }}$ of the order of $10^{3} \mathrm{M}^{-1}$.

As for anionic compounds, on the other hand, there was almost no retention for 9-anthracenecarboxylic acid, probably due to an electrostatic repulsion with poly-

Table 1 Retention of polycyclic aromatic compounds on the DNA-loaded column ${ }^{\mathrm{a}}$

\begin{tabular}{|c|c|c|c|c|c|}
\hline & \multicolumn{4}{|c|}{ Capacity factor $\left(k^{\prime}\right)^{\mathrm{b}}$} & \multirow{2}{*}{$K_{\text {ass }} \mathrm{c} / \mathbf{M}^{-1}$} \\
\hline & $\mathrm{NaCl} 0 \mathrm{M}$ & $0.01 \mathrm{M}$ & $0.05 \mathrm{M}$ & $0.1 \mathrm{M}$ & \\
\hline 9-Anthracenecarboxylic acid & $\begin{array}{ll}0 & (0.51)\end{array}$ & 0 & 0 & $0.27(0.21)$ & \\
\hline Methyl 9-acridinecarboxylate & $2.08(2.01)$ & 1.74 & 1.62 & $1.54(2.17)$ & $1.54 \times 10^{3{ }^{15}}[0.1 \mathrm{M}]$ \\
\hline Fluorene & $2.05(1.62)$ & 2.22 & 1.87 & $1.89(1.42)$ & \\
\hline 1-Pyrenebutyric acid & $3.85(4.50)$ & 4.06 & 5.20 & $5.39(16.98)$ & \\
\hline Phenanthrene & $5.36(5.16)$ & 5.62 & 5.28 & $5.11(4.17)$ & \\
\hline 4,5',8-Trimethylpsoralen & $5.56(5.12)$ & 5.00 & 3.99 & $3.98(3.14)$ & $4.0 \times 10^{3^{16}}[0 \mathrm{M}]$ \\
\hline Anthraquinone & $5.62(4.02)$ & 5.18 & 5.02 & $4.83(4.40)$ & \\
\hline Quinacrine & not detected & & & & $1.13 \times 10^{s^{17}}[0.1 \mathrm{M}]$ \\
\hline
\end{tabular}

a. The column packing used was the 1b-derivatized silica coupled with DNA. b. Results for the DNA-uncoupled, 1bderivatized silica packing are shown in parentheses. The amount of $1 \mathbf{b}$ on silica was $2.6 \mu \mathrm{mol} \mathrm{g-gel}^{-1}$. c. Association constant determined for the compound with DNA. ${ }^{15-17}$ Concentration of $\mathrm{NaCl}$ in the measurement is shown in brackets. 
<smiles>c1ccc2c(c1)Cc1ccccc1-2</smiles>

Fluorene<smiles>O=C1c2ccccc2C(=O)c2ccccc21</smiles>

Anthraquinone

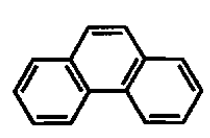

Phenanthrene<smiles>COC(=O)c1c2ccccc2nc2ccccc12</smiles>

Methyl 9-acridinecarboxylate<smiles>O=C(O)c1c2ccccc2cc2ccccc12</smiles>

9-Anthracenecarboxylic acid<smiles>CCN(C)CCNC(C)C(C)C</smiles>

Quinacrine

anionic DNA; 1-pyrenebutyric acid, however, showed a significant retention, which increased when the ionic strength was raised. The latter can be explained by the relatively long distance between the carboxylate group and the intercalating pyrene ring, leading to a reduced repulsive interaction between 1-pyrenebutyrate and DNA. Quinacrine, a positively charged compound, was not eluted due to the strong affinity $\left(K_{\text {ass }}>10^{5} \mathrm{M}^{-1}\right) .{ }^{17}$

The retention behaviors obtained for the DNAcarrying column can be consistently explained in terms of some familiar interactions with DNA. In contrast, the capacity factor on a DNA-free, psoralen-loaded column varies for each compound with no straightforward relationship; the underlying interactions seem to be too complicated to delineate in a simple manner. The nonspecific interactions observed here could pose a problem when applying DNA-immobilized packings to affinity chromatography when the surface transformation of the packings with DNA happens to be incomplete. The coupling chemistry presented, however, should be useful for a wide range of DNA-dependent bioaffinity reactions, since the method endorses a very high binding capacity.

The authors thank Drs. Yoshio Kato and Hiroyuki Moriyama of Tosoh Corporation for packing chromatographic columns. This work was supported in part by a Grant-in-Aid for Scientific Research from the Ministry of Education, Science and Culture.

\section{References}

1. P.-O. Larsson, Methods Enzymol., 104, 212 (1984).

2. D. Zoph and S. Ohlson, Nature[London], 346, 87 (1990).

3. a) P.-O. Larsson, M. Glad, L. Hansson, M.-O. Mansson, $\mathrm{S}$. Ohlson and $\mathrm{K}$. Mosbach, "Advances in Chromatography”, ed. J. C. Giddings, E. Grushka, J. Cazes and P. R. Brown, Vol. 21, p. 41, Dekker, New York, 1983. b) K. Nilsson and P.-O. Larsson, Anal. Biochem., 134, 60 (1983).

4. a) S. Ohlson, A. Lundblad and D. Zoph, Anal. Biochem., 169, 204 (1988). b) W. T. Wang, J. Kumlien, S. Ohlson, A. Lundblad and D. Zoph, ibid., 182, 48 (1989).

5. W. Müller and D. M. Crothers, J. Mol. Biol., 35, 251 (1968).

6. A. J. MacDougall, J. R. Brown and T. W. Plumbridge, Biochem. J., 191, 855 (1980).

7. B. L. Lee, A. Murakami, K. R. Blake, S.-B. Lin and P. S. Miller, Biochemistry, 27, 3197 (1988).

8. N. A. Nicola, J. KR. Kristjansson and G. D. Fasman, Arch. Biochem. Biophys., 193, 204 (1979).

9. J. W. Lown and S.-K. Sim, Bioorg. Chem., 7, 85 (1978).

10. J. T. Kadonaga and R. Tjian, Proc. Natl. Acad. Sci. USA, 83, 5889 (1986).

11. F. V. Peale, Jr., Y. Ishibe, C. M. Klinge, S. Zain, R. Hilf and R. A. Bambara, Biochemistry, 28, 8671 (1989).

12. D. Rickwood, Biochim. Biophys. Acta, 269, 47 (1972).

13. R. Blanks and L. W. McLaughlin, Nucleic Acids Res., 16, 10283 (1988).

14. T. A. Goss, M. Bard and H. W. Jarrett, J. Chromatography, 508, 279 (1990).

15. R. Fukuda and M. Takagi, unpublished result.

16. J. E. Hyde and J. E. Hearst, Biochemistry, 17, 1251 (1978).

17. W. D. Wilson and I. G. Lopp, Biopolymers, 18, 3025 (1979).

(Received Octobrer 30, 1991)

(Accepted January 14, 1992) 